\title{
Managing Knowledge Network Processes in the Commercialization of Science: Two Probiotica Discovery Processes in Finland and Sweden
}

\author{
Richard Langlais, Nina Janasik \& Henrik Bruun
}

\begin{abstract}
To learn more about the formation, transformation and interaction of knowledge networking, we studied two processes of commercialisation of scientific knowledge. Both involved a Lactobacillus strain - Lp299v, in Sweden, and LGG, in Finland - and two different companies. The first, a small science company, was established expressly to commercialise $L p 299 \mathrm{v}$, while the other, a large dairy company, sought to develop new functional food products from LGG. Both were successful, but differed in knowledge networking in the research, commercialization and stabilization phases. For Lp299v, pioneer knowledge networking dominated and commercialization unfolded more smoothly than for LGG, where modular networking prevailed. This indicates that, in science-based innovation, the balance between pioneer and modular modes of knowledge networking must be considered, and that there is a relation between modes, and the structure of the problems. New questions are raised about the challenges that various kinds and sizes of companies experience in different stages of innovation.
\end{abstract}

Keywords:Knowledge integration, commercialization of science, science-based companies

The processes by which the co-evolution of scientific research and science- and technology-based industries take place, as part of the commercialization of science, require more study (Murray, 2002). One such process, knowledge networking, is only partially understood. We know little about the micro-level devel- opment of knowledge networking, and how knowledge production and learning are affected by the particular mode of networking that is chosen. Knowing more about the processes of knowledge transformation and communication, as part of knowledge networking, is important for its organization and manage- 
ment. In this paper, we explore these issues by means of a comparison of a selected history of changes in the two innovation processes; with a particular interest in discovering the existence and workings of knowledge regimes and knowledge networks; and in discerning their stages of formation, transformation and communication. We primarily focus on modular and pioneer knowledge networking. The cases of the bacteria Lactobacillus rhamnosus GG (hereafter abbreviated according to its commercial identity as LGG) and Lactobacillus plantarum 299v (hereafter abbreviated according to its discoverers' practice as $L p 299 v$ ), display different patterns in terms of knowledge networking: in the LGG case, during the commercial phase of its development by the Finnish dairy company, Valio, much trust was placed in the modular knowledge networking mode of producing and coordinating knowledge; while nearly the entire process related to $L p 299 \mathrm{v}$ expressed a more explorative and therefore pioneer mode of knowledge networking, both before and during its commercialization in the Swedish company, Probi. We believe that the present analysis of the knowledge networking modes that were applied in the two companies is valuable, because it can help explain at least some aspects of the two processes in a novel way, as we demonstrate below.

We used qualitative methods for the study: thirty interviews were carried out, and a large amount of textual material was analysed. The first tier of interview participants was selected according to the formal positions they held in the companies; the snowball approach was used for selecting the second and later tiers of interview participants; in-depth interviews were performed, both in person and by telephone; and context was established using a variety of textual sources, from the companies' own archives as well as externally. All interviews were recorded electronically; about half of them were transcribed in their entirety, while the rest were selectively transcribed.

We begin, in the next section, by discussing how the study of knowledge networking, knowledge frameworks and knowledge regimes, and their constitutive processes, are one way of understanding the communication and implementation of different kinds of knowledge in organizational settings, including commercial contexts. After that discussion, in order to create a useful contrast that helps us to illuminate what occurs when using an analysis that is based on the conceptual framework for knowledge networking, we then describe the two cases below in two different ways. The first way is in the section that provides a conventional sketch of the histories of discovery and development of the bacteria in each of the cases, including a sketch of the innovation process in each of the companies. The second way, in the ensuing section, is to analyze the processes from the perspective of knowledge networking, using the relevant terminology from the conceptual framework where appropriate. We take a closer look at one key phase of the process in each innovation trajectory, paying closer attention to how learning and knowledge production is organized, and illustrating the ways in which the conceptual framework can be applied to perform a useful comparison.

The concluding section builds on this 
comparative approach to outline plausible explanations for some of the successes and failures in the two companies' attempts to develop new probiotica products, and highlights the need to pay close attention to the special character of a certain type of knowledge networking. By juxtaposing the two perspectives, the contrast we are looking for is evident.

\section{Knowledge Networks and the Processes of Scientific Collaboration}

Learning and the production of knowledge occur in social contexts. This is well known from the literature that describes and analyses such processes in terms of communities of practice, functional units in organizations, scientific disciplines and subdisciplines, scientific and technological platforms, scientific research programs and professional systems (Abbott, 1988; Dougherty, 1992; Fujimura, 1996; Wenger, 1998; Becher \& Trowler, 2001; Keating \& Cambrosio, 2003). Common for social systems such as these is that they affect human activities by structuring the cognitive and normative context within which learning occurs and knowledge is sought.

A knowledge regime is defined as a system of scripts that consolidate and reproduce what we call a knowledge framework, that is, a certain way of learning and knowledge production. The knowledge framework is a set of knowledge-related assumptions that an agent has when interacting with other agents in a particular context. Three components (dimensions) are distinguished in the knowledge framework: 1) the object of knowledge (the things, phenomena and/or relations that the agent seeks knowledge about);2) the methodology of knowledge generation and learning (the set of methods, instruments, learning strategies etc. that the agent uses to learn about the object of knowledge); 3) the way in which the agent perceives himself (or herself, or itself) as a knowledge producer or learner (for example: What is the purpose of learning? What kind of knowledge generator do I want to be?)

The positive aspect of knowledge frameworks is that they make learning and knowledge production more efficient. They also create, however, sociocognitive boundaries between people and are therefore a potential source of problems in interactions between people with backgrounds in distinct knowledge regimes. This has been established in many accounts of experiences from collaboration across knowledge boundaries, as well as in empirical studies of such collaboration (see Snow, 1959/ 1998; Apostel et al., 1972; Klein, 1996; Langlais \& Bruun, 1998; Wenger, 1998; Weingart, 2000; Becher \& Trowler, 2001; D'Adderio, 2001; Carlile, 2002; Tress et al., 2003;). On the other hand, we are careful not to read too much determinism into the relation between knowledge frameworks and the actions of individuals. Knowledge frameworks are cognitive guiding systems, and have causal powers only in a sense of making certain behaviours more probable than others at the aggregated level of a population sharing the same framework. At the specific level, however, individuals are active agents who constantly re-mold their particular knowledge framework. It is perfectly possible for individuals, and this often happens, to go beyond a collectively shared knowledge framework, to explore new areas of learning and knowledge production. Whenever peo- 
ple feel such a need, we say that they experience a transepistemic challenge. As will be seen further below, such experiences, and the way in which they are articulated, are of great importance for the dynamics of innovation processes.

Upon encountering a transpistemic challenge, the response is often that one seeks the expertise that one lacks through collaboration with others. We call this response knowledge networking. Knowledge networking is the activity of forming and maintaining an epistemically heterogeneous social structure, i.e., the knowledge network, as a part of some particular trajectory of learning and knowledge production. The networking process thus links knowledge agents having different knowledge frameworks to each other, and to a particular focus and a shared effort. There are several possible forms for such collaboration, and at least three main categories of knowledge networking: 1) modular, 2) translational, and 3) pioneer knowledge networking.

In modular knowledge networking each agent or group learns and produces knowledge independently from the other members of the network. Outputs, either in terms of knowledge claims or concrete products, are then communicated or sent to a coordinator, who produces the synthesis by combining and integrating these independent outputs (which, of course, are inputs for the coordinator). Translational knowledge networking refers to a process in which the members of the knowledge network communicate directly with each other by using a shared language or some other mediating structure as an interfacing device. There is then no need for a coordinator for collective learning and knowledge production. However, the knowledge producing agents or groups must learn to use the interfacing device and to translate their own knowledge claims to the shared language. Pioneer knowledge networking is even more complex, because in that process direct communication is instantiated without any stabilized interfacing device. Instead, temporary bridges between the distinct knowledge frameworks are built by the use of boundary objects - such as charts, simulations, pictures, concepts, etc. - that are plastic enough to adapt to the needs of each knowledge framework, yet robust enough to 'maintain a common identity across sites' (Star \& Griesemer, 1989: 393).

The three types of knowledge networking should be seen as ideal types. In reality, two, or even all three types can occur in parallel or intermixed in one and the same organizational process. Our typology is useful for distinguishing between the opportunities and challenges of the different forms of knowledge networking. For managers, this can imply a deeper understanding of the needs of individuals and their organization. When different forms of knowledge networking overlap, our conceptual tools can contribute to a better insight into the contradictions that complicate the work process.

\section{A Brief Historical Sketch of the Two Cases}

The history of work on $L p 299 \mathrm{v}$, compiled here from our interviews and the available published descriptions (Espelund, 1996; 1997; Jönsson, 1996; Vareman, 1999; Lagnevik et al., 2003), begins in 1984, when Stig Bengmark, Professor 
and Head of the Dept. of Surgery, Lund University Hospital, was looking for further ways to improve the health of patients recovering from major surgery. Even though the surgery itself might have been flawless, patients were often dying due to complications stemming from the state of the digestive tract in the first few days afterwards. Having already invented a new kind of tube for delivering nutrient solutions to the intestines of patients, his focus switched to the nutrient solution itself. A research project was formed to find a solution that was more natural and bulkier more fibrous - than the artificial nutrients then prevailing. In addition to Bengmark and several of his colleagues in surgery, the senior and junior scientists involved came from several other fields - food microbiology, applied microbiology, food technology - in several departments within Lund University and the nearby Lund Institute of Technology. By 1987, the first patent application was filed for $L p 299 \mathrm{v}$, and by 1990 its use in producing a fermented oatmeal soup and other developments and applications was well on its way to being established.

The bacteria was originally considered essential as a means of improving the delivery and take-up of the oatmeal soup, but its characteristics led to its becoming an important probiotic and product in its own right, with a wide range of applications in medicine, functional food and veterinary care. The bacterium was found by analyzing human biopsy samples, itself a new research procedure. Several doctoral dissertations and patents also resulted from this work.

In 1990, the involvement in the project of Kaj Vareman, a scientist and entrepreneur, moved the researchers to form a company, Probi AB, for the commercialization of their work. Exploratory partnership talks with another company, Skånemejerier (Skåne Dairies), that in 1994 would crystallize in the launch of the ProViva oat-based, berry and yoghurt drink product, also began at that time. Probi and Skånemejerier formed a joint working group for intensive collaboration in both innovation and the product development it entailed, with Probi performing the needed scientific research.

Probi was listed on the Stockholm stock exchange (NGM Equity) from 1998. The period between 1990-2000 was characterized by diversification of the product lines based on $L p 299 \mathrm{v}$, expansion of sales internationally, research on and development of other similar probiotica, and the intensive broadening of research collaboration networks. After almost fifteen years of research and product development, the years 20002003 were a period of intensive searching for major licensing agreements that would provide the company with global reach and increased status as a leading biotechnology firm in the area of probiotics. These sought-after agreements were signed, in 2003, for food additives and functional foods, with Institut Rosell Inc., and Group Danone, respectively. At time of writing (early 2004), these latter licensing agreements have contributed to increased financial stability for Probi, which in turn corresponds with its renewed emphasis on research.

The LGG strain was discovered in 1985, by Sherwood Gorbach and Barry Goldin, at the New England Medical Centre, Tufts University, in Boston. As 
they have expressed in interviews, they understand their work as building on that of several key predecessors. In 1905, E. Metchnikoff, the 1908 Nobel laureate in medicine, discovered Lactobacillus bulgaricus, while working at the Pasteur Institute. In the 1920s, Leo Rettger and his colleagues at Yale discovered and worked with the so-called 'Scavano strain' of Lactobacillus acidophilus. The L. acidophilus strain was also the object of the study that another Yale microbiologist, Louis Weinstein, had assigned to Gorbach in 1964. The results from that study, as well as from a study carried out by Gorbach and Goldin for The National Dairy Council, in 1975, were disappointing. No investigated Lactobacillus strain had shown the critical feature it must possess if it is to influence human health in any direction, i.e. the ability to implant itself in the human intestine. This had several components, which Gorbach listed in 1983. First, the strain would have to show resistance to acid and bile. Second, it would have to be able to attach to human epithelial cells. Third, it should be capable of colonizing the human intestine. Fourth, it would have to produce an antimicrobial substance. Fifth, it would have to show good growth characteristics. Lastly, it would have to have beneficial, rather than pathological, effects on human health (Gorbach, 1996). Two years of intensive screening followed. In 1985, a Lactobacillus strain that would meet all of the criteria was found. They named it Lactobacillus rhamnosus GG (GG after its discoverers), and immediately filed a US patent application, which was granted in 1987.

Although Valio was in most ways a traditional dairy company, it had an unusually strong interest in research and development, dating back to the times of A. I. Virtanen, the Finnish 1945 Nobel laureate in chemistry, so it was on the lookout for new scientific advances. Valio's SeniorVice President of R\&D, Kari Salminen, soon learned (also in 1985) of the discovery of LGG from a Finnish professor, Herman Adlercreutz. Salminen contacted Gorbach and Goldin, and by 1987 had negotiated a licensing agreement with them. The company organized its new research on several fronts: into the bacterium itself, and on its promising health aspects and production properties. The building up of new scientific collaboration networks was considered important. By 1990, the first products containing LGG - a whey drink and an unflavoured, set-type yoghurt were launched in Finland, under the Gefilus trademark. They did not meet with much success, however; the product quality was poor and marketing strategies ineffective. In the period 19921996, however, international licensing accelerated at an intensive pace. In 1996, a new attempt in the domestic market was made. Gefilus milk was launched, with an aggressive marketing campaign. The success of that campaign marked the true take-off point for Gefilus products in Finland. Ten years of research and product development, as well as several marketing attempts, had been required before the innovation finally succeeded. Since 1996, Valio has concentrated mainly on consolidating its earnings from the earlier work. By 2000, 27 countries had products containing LGG on the market, and the Gefilus product range had expanded significantly (Mäyrä-Mäkinen, 2000). At time of writing (early 2004), it appears that, with respect to LGG, this is the company's main con- 
tinuing strategy.

\section{Two Contrasting Processes of Knowledge Network Transformation}

In this section, we provide illustrative analyses of the two cases using the conceptual framework for knowledge networking that we have been developing. The accounts are at different resolutions. The $L p 299 \mathrm{v}$ account focuses primarily on the initial phase of the research and discovery process, whereas the LGG account sketches the entire process to date, but with a coarser resolution than the former. Our intention is to prepare for the comparative analysis in the concluding section by bringing certain aspects of the two innovation processes those related to the organizational and cognitive structure of knowledge production - into light.

\section{Knowledge Network Analysis: Lp299v}

The beginning of the process that led to the discovery of Lactobacillus plantarum $299 v$ ( $L p 299 v$ ) in 1984, was within a knowledge regime (knowledge regime 1 , or KR 1) delineated by the needs and knowledge framework of surgery, postoperative recovery and intensive care, and the institutional setting of Lund University Hospital. A transepistemic challenge (transepistemic challenge 1 , or TC 1) was experienced by surgeons, in the form of a growing understanding of the dangerous and life-threatening condition that patients were in during the first few days after major surgery. In one part of a two-part response to the challenge, one of the senior surgeons, Stig Bengmark, determined that a new method of providing nutrition for a patient intestinally was required in order to prevent organ collapse, and death. The second part of the response was provided by Bengmark and another colleague in surgery, Bengt Jeppsson, who had long been interested in the particular nutritional needs of surgery patients. These two participants in the initial medical and surgical - knowledge regime, KR 1, took further steps to meeting the challenge by deciding to learn from, and do research with, food scientists and microbiologists.

When the two surgeons proceeded to act upon their decision, by contacting prospective specialists and asking for their help, they and their respective knowledge regime embarked upon the first phase of pioneer knowledge networking in the $L p 299 \mathrm{v}$ discovery process. They recognized that their own knowledge frameworks, and the regime that sustained them, were insufficient to the task at hand, so participants from other disciplines, each with knowledge that was too inaccessible for the surgeons, were required. The way of working would allow a great deal of independence and room for individual initiative on the part of each of the participants in the eventual project the surgeons were contemplating. This freedom and the relative lack of central coordination of each researcher's work by the project's founders, were the hallmarks of the pioneer knowledge networking they were embarking upon.

As a result of the first phase of pioneer knowledge networking, the surgeons who made up the first research group (as a part of KR 2), in recruiting new collaborating specialists from other institutions, had created a new field of contact with 
Table 1. The process of knowledge networking in the case of Lp299V.

\begin{tabular}{|c|c|c|c|c|}
\hline & & Action & KN mode & Result \\
\hline $\begin{array}{l}\text { KR } 1 \\
\text { Needs and knowledge } \\
\text { framework of surgery, } \\
\text { postoperative } \\
\text { recovery and intensive } \\
\text { care (Lund University } \\
\text { Hospital) }\end{array}$ & $\begin{array}{l}\text { TC } 1 \\
\text { How could patients' } \\
\text { recovery after major } \\
\text { surgery be improved? }\end{array}$ & $\begin{array}{l}\text { Problem definition: } \\
\text { a new method is } \\
\text { required for pro- } \\
\text { viding nutrition for } \\
\text { a patient intestinally } \\
\text { Collaboration with } \\
\text { food scientists } \\
\text { and microbiologists }\end{array}$ & Pioneer & $\begin{array}{l}\text { Formation of } \\
\text { knowledge regime } 2 \\
\text { A method was } \\
\text { selected: } \\
\text { Tube delivery of } \\
\text { nutrients directly } \\
\text { to the intestines }\end{array}$ \\
\hline \multirow[t]{2}{*}{$\begin{array}{l}\text { KR } 2 \\
\text { KR } 1 \text { (Lund University } \\
\text { Hospital) plus food } \\
\text { technology \& applied } \\
\text { microbiology } \\
\text { (Chemistry Center, } \\
\text { Lund University \& } \\
\text { Lund Institute of } \\
\text { Technology) }\end{array}$} & $\begin{array}{l}\text { TC } 2 \\
\text { What kind of } \\
\text { nutrient? }\end{array}$ & $\begin{array}{l}\text { Exploring the } \\
\text { nutrient issue from } \\
\text { different } \\
\text { perspectives }\end{array}$ & Pioneer & 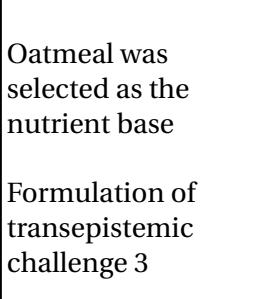 \\
\hline & $\begin{array}{l}\text { TC } 3 \\
\text { Could bacteria be } \\
\text { used to pre-digest } \\
\text { the oatmeal? }\end{array}$ & $\begin{array}{l}\text { Experiments with } \\
\text { bacterial pre- } \\
\text { digestion of oatmeal } \\
\text { Animal experiments } \\
\text { Search for the } \\
\text { bacterium that was } \\
\text { to later become } \\
\text { known as } L p 299 \mathrm{v}\end{array}$ & Pioneer & $\begin{array}{l}\text { Formation of } \\
\text { knowledge regime } 3 \\
\text { Identification } \\
\text { of } L p 299 \mathrm{v}\end{array}$ \\
\hline $\begin{array}{l}\text { KR } 3 \\
\text { KR } 2 \text { plus more micro- } \\
\text { biology expertise and } \\
\text { more surgeons from } \\
\text { the organizations } \\
\text { already involved }\end{array}$ & $\begin{array}{l}\text { TC } 4 \\
\text { How can Lp299v } \\
\text { be commercialized? } \\
\text { Are there other bacilli } \\
\text { with interesting } \\
\text { properties? }\end{array}$ & $\begin{array}{l}\text { Partnership for } \\
\text { commercializing } \\
\text { Lp299v with } \\
\text { Skånemejerier } \\
\text { Collaboration with } \\
\text { researchers in } \\
\text { Sweden and abroad }\end{array}$ & Modular & $\begin{array}{l}\text { Formation of } \\
\text { knowledge regime } 4\end{array}$ \\
\hline $\begin{array}{l}\text { KR } 4 \\
\text { KR } 3 \text { plus Skåne- } \\
\text { mejerier plus network } \\
\text { of researchers at } \\
\text { universities in Sweden } \\
\text { and abroad }\end{array}$ & $\begin{array}{l}\text { TC } 5 \\
\text { What } L p 299 v \text {-based } \\
\text { products can be } \\
\text { developed? } \\
\text { How can these } \\
\text { products be } \\
\text { commercialized? }\end{array}$ & $\begin{array}{l}\text { Product } \\
\text { development group } \\
\text { from Probi and } \\
\text { Skånemejerier } \\
\text { coordinates } \\
\text { numerous trials and } \\
\text { studies and surveys. }\end{array}$ & $\begin{array}{l}\text { Modular/ } \\
\text { pioneer }\end{array}$ & $\begin{array}{l}\text { Development of } \\
\text { ProViva line of dairy } \\
\text { products (e.g. } \\
\text { yoghurt) and sport } \\
\text { recovery and } \\
\text { other drinks }\end{array}$ \\
\hline
\end{tabular}


two other knowledge regimes, those of food technology and applied microbiology, within different sections of the Chemistry Center, run jointly by Lund University and the Lund Institute of Technology. The impact of the new contacts was that they expanded the knowledge framework of the participants of the original knowledge regime to the extent that, from the point of view of the discovery process, a new knowledge regime (KR 2) was formed. The total range of knowledge now accessible to the project was radically expanded. This new knowledge regime was a combination of the knowledge frameworks and knowledge regimes of the now expanded number of participants in the process.

The initial pioneer knowledge networking done by the surgeons, already described above as being focused on two things - the search for a method of providing nutrients (only partially solved at that time), and on the identification and formation of an enlarged team of collaborators for doing it (solved for that phase of the process) - in itself also led to a redefinition of its goals, and in an expansion of the scope of the original transepistemic challenge, to become the new transepistemic challenge (no. 2) for the new, second, knowledge regime. This reformulation of goals and scope was achieved through discussions between all of the collaborators, both the original surgeons and the newly-invited specialists, who then proceeded with their collaboration through a further set of steps of pioneer knowledge networking.

During the second knowledge regime, the first steps in pioneer knowledge networking were taken by the lead food scientist, Kåre Larsson, whose entry had been part of the original regime's much- needed expansion. His presence and his proposal were a response to the previous transepistemic challenge, which included the search for a novel nutrient delivery method. Proceeding on the basis of his own knowledge framework, in cereals research, he proposed that oatmeal should be the nutrient base of choice, but since it would have to be delivered by tube directly to the intestines (this choice was after all the conclusion of the initial phase of the pioneer knowledge networking), it would miss the stomachs digestive treatment. This meant that the oatmeal would first need to be processed in some other way, so as to make it more suitable for digestion in the intestines. This answer to part of the previous challenge - i.e. 'What kind of nutrient?' - formed in turn the basis of the next new challenge for the expanded research group (KR 2). In a clear exercise of continued pioneer knowledge networking, where each member of the network contributed to the decision, the integration and the exploration, the surgeons, the food scientist and the initial lead microbiologist, Nils Molin, through further discussion agreed with Larsson's proposal that using bacteria to pre-digest the oatmeal might indeed work, and should be tried. This proposal, or rather, the posing of it as a new research goal, became yet another transepistemic challenge (TC 3).

Meeting this new challenge required an expansion of the knowledge frameworks, especially in microbiology and surgery, so the number of participants was increased with more specialists. Nils Molin recruited Göran Molin, Siv Ahrné, Clas Lönner, Ingela Marklinder, and Marie-Louise Johansson. They were all researchers working in proximity to Nils 
Molin at Lund University's Department of Microbiology who, when taken together, represented expertise in a wide variety of specializations. The knowledge framework was also increased by the inclusion of several more surgeons who would be involved in the provision of human tissue samples for the various experiments and tests at Lund University Hospital (Espelund, 1997). This expansion of the knowledge framework via the new, now third phase of intensive pioneer knowledge networking, created such a strong redefinition of the nature of the project and the character of the research that it was, essentially, the formation of the third generation knowledge regime (KR 3), which would search for the bacterium that was to later become known as Lactobacillus plantarum $299 \mathrm{v}$.

This pattern of organizing the research continued in a similar fashion, dominated by pioneer knowledge networking, as $L p 299 \mathrm{v}$ was discovered, explored and put through a variety of trials. It must be added that even a casual survey of the productivity and interactivity of the pioneering knowledge network that was evolved around the many aspects of $L p 299 \mathrm{v}$ shows that serious collaboration between the various research groups and individuals was noteworthy, fruitful and far-reaching. International conferences were organized through their company, Probi, an awardwinning newsletter was published several times yearly, and numerous joint research projects were established involving researchers from many countries on several continents, which the authorship of articles forming the basis for related $\mathrm{Ph}$.D. dissertations confirms (e.g., Johansson et al., 1995; Berggren et al., 1996; Antonsson et al., 2001).

For present purposes, it is not necessary to continue chronologically with the style of the analysis above, since the purpose of illustrating the knowledge networking perspective on the initial phase has been sufficiently met. Instead, jumping ahead, after half-a-decade's work it was clear for the researchers that it was desirable to commercialize the knowledge products that they had generated. The overall knowledge regime that had been progressively organized and expanded for continuing to search for and do research on beneficial Lactobacillae remained, and experienced many successes, but at the point of seeking a path for the commercialization of Lp299v, a shift and split in the knowledge frameworks occurred. This led to the formation of a radically different kind of knowledge regime (KR 4), based on the previous one, certainly, but extended with two new components, or subknowledge regimes: 1) the continued search for and exploration of other Lactobacillae; and 2) the further research specifically into $L p 299 \mathrm{v}$ itself, and research and development into appropriate forms for its successful commercialization. Pioneer knowledge networking continued to be important for both, where research was involved; but for the latter, a strong element of modular knowledge networking was influential in the success of the product development. This arose because, after a period of negotiations with several companies, and the establishment of Probi AB (this is a story in its own right) by the now-expanded group of researchers who were participating in the various projects related to Lactobacillae, a partnership for commercializing Lp299v was entered 
into with the company, Skånemejerier AB (Skåne Dairies), based in nearby Malmö. A project team made up of individuals from both Skånemejerier and Probi was formed, for centrally coordinating, integrating and directing the development of health food products containing $L p 299 \mathrm{v}$ by a network of researchers working not only in the region, but elsewhere in Sweden and abroad. This was a form of modular knowledge networking with elements of pioneer knowledge networking, since it was clear that the lively traditions of research that many of those in the coordinating group were accustomed to was open to independent, innovative development initiatives from its collaborators.

While the combined exploration and exploitation period from 1990-2000 led to the intensive broadening of research collaboration networks for both $L p 299 \mathrm{v}$ and other probiotica strains, diversification of the products based on $L p 299 \mathrm{v}$ and growing international sales, the years 2000-2003 had another focus. After almost fifteen years of research and product development, with consistent leadership, Probi had three different CEOs in a three-year period up to 2003. This latter period was a time of concentrating on the search for major licensing agreements that would provide the company with security, global reach and greater status as a leading biotechnology firm in the area of probiotics (Wallter, 2002). Happily for the company, these longed-for agreements were signed, in 2003, for food additives and functional foods, with Institut Rosell Inc., and Group Danone, respectively, in effect leading to worldwide coverage for Probi and $L p 299 \mathrm{v}$.

The shift to the financial and market- ing focus of the company, in 2000 and afterwards, had a corresponding impact on the research side. Efforts were made by participants in each of the components of the knowledge regime of the time to bridge the now widening knowledge gap: research, on the one hand, and finance and marketing on the other, had a mutual feeling that the other side didn't understand the premises, knowledge and expectations of the other. Joint information meetings were held, but the research component shifted in emphasis to clinical trials, and away from basic research, with a period of turnover of research staff reflecting this. At time of writing (early 2004), the most recent CEO has taken advantage of the success in having achieved the long sought-after licensing agreements to re-inject energy into new research collaborations, at the same time as innovation and clinical testing in already proven domains is proceeding at pace. The two main components, research and finance, of the main knowledge regime, probiotics at Probi, are both poised for mutually-enhancing growth.

\section{Knowledge Network Analysis: LGG}

In the LGG case, our focus is widened so as also to include the product development and commercialization phases of innovation. In contrast to Probi, which externalized much of the product development - that is, the development of dairy and other products that contain the bacterium - in joint projects with other companies, Valio did that primarily on its own. Consequently, this case expresses more diversity of knowledge networking contexts than does our analysis of the $L p 299 \mathrm{v}$ case. 
The discovery of LGG began in a knowledge regime that two scientists, Sherwood Gorbach and Barry Goldin, participated in during the mid-1970s (knowledge regime 1). Although of diverse backgrounds, they worked in the same laboratory, had the same source of funding and many of the same colleagues. The results of Gorbach's earlier Lactobacilli work had been so unpromising that he had eventually given up. He returned to it, however, by chance. On an otherwise normal day at the laboratory, a colleague - an endocrinologist 'working across the hall' - mentioned just in passing that there was a grant program being launched by the National Dairy Council, and that it contained ideas that might affect the dairy industry with regard to research. Sensing an opportunity, Gorbach and Goldin quickly wrote up a proposal where they 'threw in' some content about Lactobacilli and sent it off. It was accepted, and they returned to their earlier search for any scientific basis for thinking that eating Lactobacilli was beneficial to consumers. Whether any clinical benefits could be verified became the over-arching transepistemic challenge (transepistemic challenge 1), a complex research problem that required collaboration via new knowledge networking with numerous researchers external to, rather than within, the confines of their current knowledge regime.

Based on the insights produced through this pioneer knowledge networking, which was gradually resulting in a new, extended knowledge regime (knowledge regime 2), the desired strain and indications of a beneficial health effect were found, in 1985. Gorbach and Goldin began investigating the commercial possibilities, which became their next transepistemic challenge (transepistemic challenge 2).

ForValio, the company in Finland that would eventually acquire the rights to LGG, the discovery of a promising Lactobacillus strain came at a good time. Its decades of scientific orientation made it well equipped for new transepistemic challenges. This fundamental orientation towards R \& D forms the epistemic base for the innovations that would follow later, and was an essential part of the company's knowledge regime during the later initiation of the LGG project (knowledge regime 3 ). Moreover, in the early 1980s, a probiotic ideology had gained support, which formed a foil for a new transepistemic challenge that had also been emerging. Some members of the R\&D department were seeking a scientific way of developing probiotica, although their initial knowledge-networking attempts were disappointments. When they tried to engage Finnish researchers, most of them laughed at their idea, considering it a dead end. The group from R\&D then contacted Adlercreutz (the Finnish professor) who, due to his previous collaboration with Gorbach and Goldin on estrogen research, was familiar with the pair's recent discovery of the LGG strain. Gorbach and Goldin were contacted, leading to the 1987 licensing agreement that gave Valio global rights to the LGG strain. The linking of the medical knowledge regime (knowledge regime 2) in Boston, on the one hand, with the knowledge regime at the relatively small, traditional - although scientifically rather advanced - Finnish dairy company, on the other (knowledge regime 3) led to modular knowledge networking, with its clear separation of tasks and central coordination by Valio. 
Table 2. The process of knowledge networking in the case of LGG:

\begin{tabular}{|c|c|c|c|c|}
\hline & & Action & KN mode & Result \\
\hline \begin{tabular}{l|} 
KR 1 \\
Multidisciplinary \\
research on the \\
intestinal effects of \\
diet in relation to \\
cancer (Lab in Tufts, \\
New England Medical \\
Center, Boston)
\end{tabular} & $\begin{array}{l}\text { TC } 1 \\
\text { Do Lactobacilli have } \\
\text { any beneficial } \\
\text { effects on human } \\
\text { health? } \\
\text { Can this be verified? }\end{array}$ & $\begin{array}{l}\text { Collaboration with } \\
\text { other researchers } \\
\text { who were studying } \\
\text { the survival } \\
\text { characteristics of } \\
\text { various Lactobacillus } \\
\text { strains, toxogenic } \\
\text { E. coli, and viral } \\
\text { diseases }\end{array}$ & Pioneer & $\begin{array}{l}\text { Formation of } \\
\text { knowledge } \\
\text { regime } 2 \\
\text { The desired LGG } \\
\text { strain was } \\
\text { identified; clear } \\
\text { indications of } \\
\text { health effects }\end{array}$ \\
\hline \begin{tabular}{l|} 
KR 2 \\
Multidisciplinary \\
research on the cha- \\
racteristics of the $L G G$ \\
strain (Labs in Tufts, \\
New England Medical \\
Center, Boston)
\end{tabular} & $\begin{array}{l}\text { TC } 2 \\
\text { How can the } \\
\text { LGG discovery be } \\
\text { commercialized? }\end{array}$ & $\begin{array}{l}\text { Search for a } \\
\text { suitable partner }\end{array}$ & Modular & \\
\hline $\begin{array}{l}\text { KR } 3 \\
\text { Valio: traditional } \\
\text { dairy company with } \\
\text { investments in } R \& D \text {, } \\
\text { and a probiotic } \\
\text { ideology }\end{array}$ & $\begin{array}{l}\text { TC } 3 \\
\text { Is there a scientific } \\
\text { basis for probiotic } \\
\text { dairy products? }\end{array}$ & $\begin{array}{l}\text { Negotiations with } \\
\text { both Finnish and } \\
\text { foreign scientists; } \\
\text { Gorbach \& Goldin } \\
\text { contacted }\end{array}$ & $\begin{array}{l}\text { Modular } \\
\text { (with KR 2) }\end{array}$ & $\begin{array}{l}\text { Valio gets global } \\
\text { rights to the LGG } \\
\text { strain (1987) }\end{array}$ \\
\hline \begin{tabular}{l|} 
KR 4 \\
The LGG knowledge \\
regime; making a \\
scientifically-justifiable \\
health-promoting \\
product (Valio)
\end{tabular} & $\begin{array}{l}\text { TC } 4 \\
\text { How can experts, } \\
\text { consumers and the } \\
\text { skeptics in Valio be } \\
\text { convinced of the } \\
\text { feasibility of the new } \\
\text { LGG-based product } \\
\text { concept? }\end{array}$ & $\begin{array}{l}\text { Collaboration with } \\
\text { researchers in } \\
\text { Finland \& abroad; } \\
\text { across department } \\
\text { boundaries at Valio }\end{array}$ & 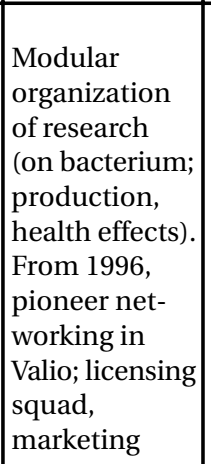 & $\begin{array}{l}\text { The launch of the } \\
\text { first Gefilus } \\
\text { products (1990); } \\
\text { scientific evidence } \\
\text { of the beneficial } \\
\text { effects of LGG } \\
\text { (1990-1992); } \\
\text { international } \\
\text { sub-licensing } \\
\text { agreements }\end{array}$ \\
\hline $\begin{array}{l}\text { KR } 5 \\
\text { The traditional } \\
\text { knowledge regime: } \\
\text { the processing, } \\
\text { developing, marketing } \\
\text { and selling of } \\
\text { commodity dairy } \\
\text { products (Valio) }\end{array}$ & $\begin{array}{l}\text { TC } 5 \\
\text { How can high- } \\
\text { quality dairy } \\
\text { products be } \\
\text { produced and distri- } \\
\text { buted efficiently? } \\
\text { How can sales } \\
\text { figures be improved? }\end{array}$ & $\begin{array}{l}\text { Applied research on } \\
\text { process technology; } \\
\text { analyze and forecast } \\
\text { market changes; } \\
\text { develop distribution } \\
\text { net. Resistance to } \\
\text { KR } 4\end{array}$ & $\begin{array}{l}\text { Modular } \\
\text { (departmental } \\
\text { responsibilities) }\end{array}$ & $\begin{array}{l}\text { Broad, high- } \\
\text { quality commodity } \\
\text { product } \\
\text { sortiment; } \\
\text { financial returns } \\
\text { for the national } \\
\text { milk producers }\end{array}$ \\
\hline $\begin{array}{l}\text { KR } 6 \\
\text { The LGG knowledge } \\
\text { regime plus marketing } \\
\text { department (Valio) }\end{array}$ & $\begin{array}{l}\text { TC } 6 \\
\text { Marketing strategies: } \\
\text { How to } \\
\text { communicate to } \\
\text { consumers? }\end{array}$ & $\begin{array}{l}\text { Development of } \\
\text { novel marketing } \\
\text { strategies }\end{array}$ & Pioneer & $\begin{array}{l}\text { Commercial } \\
\text { success with } \\
\text { Gefilus products } \\
\text { (1996 onwards) }\end{array}$ \\
\hline
\end{tabular}


It also solved two transepistemic challenges at once (transepistemic challenge 2 and 3): the American researchers found a suitable partner whose knowledge framework also included expertise for commercializing LGG; and Valio found a way to expand its own knowledge frameworks so that health-promoting Lactobacilli could be commercialized in a more scientific manner.

Although we can say that two new knowledge regimes resulted from this modular knowledge networking, this is a simplification, since in practice many knowledge perspectives, such as different $R \& D$ and marketing strategies, figured in both knowledge regimes. Nevertheless, a distinct regime was formed by those who, representing knowledge perspectives from several departments, in some way grasped the - for them - new and odd idea of making a scientifically justifiable, health-promoting product (knowledge regime 4, or the LGG knowledge regime). The second regime consisted of those who, likewise from a variety of perspectives, were more inclined towards the company's traditional mission, i.e. the production of commodity dairy products (knowledge regime 5 , or the traditional knowledge regime).

The 'LGG regimers' soon found themselves confronted with the imposing transepistemic challenge (no. 4) of convincing experts, consumers and Valio personnel who were not yet used to the feasibility of the new product concept. To create conviction via science, the LGG regimers continued in a modular manner, separating the research into the bacterium itself, its production conditions and its health benefits. The first two were conducted within the company, whereas the third became the task of the exter- nal research network that was quickly built up, consisting of foreign as well as domestic researchers. Here, mobilization was effective, enrolling as it did health professionals and others who later were to become world-class researchers in probiotics. Finally, in 1990, the first products containing LGG, a whey drink and an unflavoured, set-type yoghurt, were launched in Finland under the brand name Gefilus, but the results were discouraging.

Affecting this failed first attempt at domestic commercialization was the inability of the LGG knowledge regime to integrate the crucial $R \& D$ and marketing knowledge perspectives. By 1993, the added failure of the international sublicensing endeavour almost led to Valio's cancellation of the entire project. Those in the company who were already critical became emboldened, and even some of the believers began to equivocate. So what explains the fact that the entire project was not taken off the agenda?

An adequate answer has many aspects, such as the time and money already invested, and the capacity to convince management to continue. Here, we emphasize three aspects of the process. Firstly, the early mobilization of the network of scientists began to pay off as publications on the beneficial effects of LGG began to appear (e.g. Isolauri et al., 1991; Goldin et al., 1992); the increase in scientific credibility encouraged companies interested in sub-licensing agreements. Secondly, in 1992, as a result of a breakthrough in international sub-licensing, to a Dutch company, the LGG knowledge regime changed, with the opportunistic formation of a self-appointed 'informal licensing squad'. Most visibly, the senior manager and the law- 
yer on the squad embodied the knowledge perspectives of science, international operations and law. The group travelled around the world at a fervent pace and were able to negotiate a suite of agreements. In view of the highly formal work patterns of the company, this activity was unique. Thirdly, we mention above that one crucial task for the LGG knowledge regime was to win over the rest of Valio's personnel. Perhaps nowhere else does the difference between the LGG knowledge regime and the traditional knowledge regime show up more clearly than in the communication between the highly science-driven LGG regimers and the marketers from the traditional knowledge regime. The short time spans of marketing contrasted starkly with the long-term operating principles of the LGG regime. The situation changed radically in 1996, when a new marketing member of the traditional knowledge regime took up the domestic aspect of the transepistemic challenge for commercialization (i.e. transepistemic challenge 4) and became more closely engaged with the LGG knowledge regime. Whereas communication across this critical interface had previously been unfruitful, it now intensified through a number of conjoint meetings. A crucial aspect of these occasions of pioneer knowledge networking was to create a deep understanding of the LGG concept for the new marketing member, positioned somewhat lower in the organizational hierarchy, and much time was spent doing so.

Based on these intense and frequent occasions of successful pioneer knowledge networking, which resulted in the transformation of the original LGG knowledge regime to a renewed one (knowledge regime 6), an advertising agency was hired. The notion of 'bacteria to the rescue' was devised, a formulation that contrasted starkly with the then-surfacing discussion of antibioticsresistant 'killer bacteria'. Despite cautions from the R\&D members of the LGG knowledge regime, the new marketing 'converts' pulled off an intensive campaign that intentionally pushed the limits of Finnish legal restrictions. Although the company later had to retreat on some of its most blatant marketing excesses, they had already paid off, as seen from the rise in sales figures from 1996 onwards. That year marks the upbeat end of the multi-faceted struggle for conviction and concept explication that the LGG knowledge regime initiated in 1987. Upon superficial analysis, it would seem that the years that followed were mainly ones of solid stabilization of the LGG concept within the renewed LGG knowledge regime, nationally as well as internationally. From the point of view of knowledge networking, however, plain stabilization is not the last word.

In 1998, there was a rupture in the external scientific network. The company redifined its relationship to basic research, which changed the specific forms of the remaining collaborations and, at the same time, the LGG knowledge regime (now knowledge regime 7). Presently, Valio has the challenge of sustaining its successes into the future (transepistemic challenge 6), even if the most intense years of knowledge networking seem to have passed; the general form of the LGG innovation process is of a bell curve: a hesitant start in the 1980s; a transepistemic peak in the mid-1990s; and, towards the end of the decade, a gradual waning. We conjecture that this 
can be explained as sedimentation and reification of the patterns of knowledge networking that the LGG knowledge regime created within the company. Recapitulating, however, the description above is not of sales figures, or the like, but about the internal transepistemic dynamics of the process.

\section{Discussion}

This paper interprets two innovation processes, employing the emerging conceptual platform based on the notions of knowledge regime, knowledge framework, and knowledge networking. In this paper, our central aim is to apply the concept of knowledge networking, and to illustrate its significance in understanding and explaining the so different processes behind such apparently similar results as the discovery of LGG and $L p 299 \mathrm{v}$ and their eventual role as products. In the sections above, we describe the conceptual platform we use in studying the processes of knowledge networking; present brief descriptions of the companies, their products, and the different historical trajectories behind these; and examine in detail the knowledge networking involved in both trajectories. Two tasks thus remain for this concluding section. First, we show what really was different between the two cases, in terms of our conceptual framework. Second, we briefly discuss what our conceptual framework does for understanding the process of knowledge networking as part of the research and innovation activities and as part of the history of these companies with respect to the two bacteria.
Transepistemic Challenges and Knowledge Networking in the Research Phase

The first noteworthy difference between the LGG and Lp299v cases is the way the first phase of 'pure' research unfolded. Whereas the transepistemic challenge of finding a bacterium that would adhere to the intestine in a health-promoting manner, and the pioneer knowledge networking undertaken in response to this challenge, were relatively straightforward in the case of LGG, leading to the notion of its commercialization at an early stage of the research process, the research phase of $L p 299 \mathrm{v}$ witnessed not just one clearly formulated transepistemic challenge, but many reformulations of the challenge, resulting in a wave-like back-and-forth motion between the challenges and the pioneer knowledge networking undertaken in response to them.

Thus, although the type of knowledge networking that dominated the research phases in both cases is clearly pioneering, the phase in the LGG case appears to be both shorter and structurally much less complex than the corresponding one for $L p 299 \mathrm{v}$. This difference appears to be correlated to the actual nature of the transepistemic challenge itself, and to how it was perceived by the actors. In the case of LGG, the initial transepistemic challenge - to find a bacterium that would adhere to the intestine and be good for health - although intricate, was still better structured than that of $L p 299 \mathrm{v}$, which was to find a new way of providing nutrition for patients recovering from heavy surgery. This is also reflected in the relative ease with which knowledge networking turned modular 
in the case of LGG, as compared with the continuance of pioneer networking in the case of $L p 299 \mathrm{v}$. As is shown in the interpretative narratives, the notion of externalized commercialization based on modular principles had already been formulated by LGG's discoverers themselves.

Based on these preliminary findings, we consider that more analytical work needs to be done in distinguishing different kinds of transepistemic challenges from each other, and in relating them to the already existing typology of knowledge networking. In which cases is pioneer knowledge networking the best way forward, and in which would the other two types of networking be more suitable? Could one for instance discern a spectrum of transepistemic challenges, from more successfully defined to more open-ended, with a corresponding emphasis on modular vs. pioneer knowledge networking, and with some kind of critical dividing line somewhere in-between? These are questions to be addressed in our continued research.

\section{Contrasting Knowledge Networking Patterns in the Commercialization Phase}

A second noteworthy difference between the two innovation trajectories can be discerned in the way the next phase of the process, which was that of commercialization, occurred. As the interpretative narratives show, the emphasis on - or, as one would be more inclined to say, the forces of - modular knowledge networking persisted in the case of LGG despite conscious attempts in creating pioneer knowledge networking, whereas the pioneering element re- mained at the forefront all along in the case of $L p 299 \mathrm{v}$, although it was combined with a kind of modified form of modularity, especially in its initial commercialization (cf. the above section).

In the case of LGG, commercialization took place within an organization that is itself organized in a heavily modular manner, both generally and with respect to its R\&D department. Although it was realized at an early stage that the commercialization of the new product required communicative actions within Valio that would be more along the lines of pioneer, rather than modular, knowledge networking, in practice this was at first difficult to achieve, both for international and national commercialization. In both cases, the problem was solved by going directly against the 'gravitational' forces of existing organizational structures, and creating specific 'task forces' for both, within which knowledge networking could successfully combine the modular and pioneer modes. Internationally, the licensing squad came to dominate commercialization for years to follow. Nationally, organizational hierarchies were disregarded. It appears that these difficulties in pushing through pioneer knowledge networking at least to some extent delayed this phase of the LGG process. Again, the $L p 299 \mathrm{v}$ process forms a stark contrast to that of LGG. A high degree of consensus seemed to modulate the consistent and rather free-flowing collaborative effort, which appears to suit the needs of, and even be essential in constituting, a pioneer knowledge networking endeavour.

Based on our preliminary analysis, we conclude that commercialization of products such as LGG and $L p 299 \mathrm{v}$ need 
a delicate balance between modular and pioneering knowledge networking. From the point of view of a traditional company, the heavy pull of departmentbased modular knowledge networking needs to be consciously and actively counteracted. As we discuss in the next paragraphs, this is indeed happening currently, at an organizational level in the home base of LGG. From the point of view of Probi, the 'science company', the knowledge networking challenge would appear to be exactly the opposite, i.e. to introduce elements of modularity into the commercialization process.

On its own, our second conclusion would not seem to be anywhere near as radical, or even original. After all, it has been known for ages that traditional companies can be organizationally stiff and that science companies need to work on the commercialization aspect. As we see it, the added value of our analysis of that stage of development lies not so much in the results of the analysis as in the fact of conducting it: it is one thing to be simply aware of a challenge, and quite another to open up the black box of understanding and explaining it. As opposed to the former, the latter provides us with the possibility of actually doing something constructive about it in the future. One can ask then how, more precisely, was pioneer knowledge networking induced into the modular structures within which LGG developed, and how can knowledge about this aid other actors, the number of which are certainly increasing, facing the same kind of situation? What was the secret, from the point of view of knowledge networking, behind the successful realization of the $L p 299 \mathrm{v}$ commercialization process, and what can other science companies facing the same challenge learn from it? Our work in progress goes further with these questions.

\section{Contrasting Paths of Knowledge Networking in the Stabilization Phase}

A third difference between the two innovation trajectories can be discerned in relation to what has happened since the initial commercialization of products containing either LGG or $L p 299 \mathrm{v}$. The dominant tendency of the work done with LGG appears to be to continue consolidation of the LGG knowledge regime, which is reflected primarily in the growth of the LGG product family (cf. the section on its history, above). As opposed to this, the dominant trend in the work on $L p 299 \mathrm{v}$ seems to be that of continued pioneering activity, as witnessed for example, in the bringing to market of new and innovative $L p 299 \mathrm{v}$-containing products such as the recovery drink ProViva Active. Again, this is perhaps hardly surprising in view of the difference in basic character of the two commercial contexts.

Again, however, we hasten to add caveats to this rather too straightforward picture. Although perhaps not reflected in the $L G G$ process itself, the period after its final, successful commercialization has been one of major changes, both in the $R \& D$ department and in the overall company. Towards the end of the 1990s, the significance of products with high added value had been steadily increasing within the company, leading to a corresponding higher emphasis on this aspect of the company's activity. This is also reflected in the organizational restructurings of the company, especially of its $R \& D$ department, towards more 
integrative approaches. With respect to the $R \& D$ department, it appears that the main tendency today is indeed to strengthen the pioneering element through organizational rearrangements. Accordingly, the innovations brought forward since the mid-1990s have been developed within the confines of this renewed organization.

As for Probi, the company that has been commercializing $L p 299 \mathrm{v}$, the late 1990s and the first years of the current decade witnessed a tendency of moving towards the opposite of the development described above, i.e. towards placing a heavier emphasis on the commercial, modularly-oriented aspect of the company's activities. Most recently, though, emphasis has again shifted back to research (cf. the section on its history, above). Thus, although the $L p 299 \mathrm{v}$ process appears to have been generally more oriented towards pioneer knowledge networking, its most recent history reveals that also working along modular lines is as critical for it as working along pioneering lines is for the other company. In other words, the general transepistemic challenge of balancing modular with pioneer knowledge networking remains as central as ever for both companies, although, as we have seen, they approach this challenge from diametrically opposite directions.

Summing up, what was different in the three stages of the innovation process was that a) the natures of the transepistemic challenges involved at the research stage were not identical, with the $L p 299 \mathrm{v}$ process involving a significantly less clear and structured transepistemic challenge than the LGG process, although the response in both cases was that of pioneer knowledge networking, and that b) the pioneering element in the process of commercializing $L p 299 \mathrm{v}$ was stronger than in the process of commercializing LGG, resulting in less friction in resolving that transepistemic challenge, and finally c) the $L p 299 \mathrm{v}$ process has maintained its propensity for pioneer knowledge networking at later stages, while the LGG process has been more inclined towards modularly organized utilization.

The two case studies suggest that pioneer knowledge networking plays an important role in science-based innovation processes, and that special attention should be directed at its management, not only in itself, but also in conjunction with other forms of knowledge networking, especially modular knowledge networking. Our research suggests that there is a certain correlation between the problem structure of transepistemic challenges, on the one hand, and the optimal knowledge networking response, on the other. It seems that the cognitive and social mechanisms of pioneer knowledge networking are particularly appropriate for resolving problems that are poorly defined, which is often the case when radical ideas are introduced. For example, in the case of Valio, we saw that, even within its own company, the LGG regime had great difficulties in diffusing its functional food concept. This was because that notion did not fit with the dominating knowledge framework, and the departmental (modular) organization of Valio created barriers to direct communication and the creation of shared boundary objects. In this sense the Probi process was smoother.

On the other hand, as soon as the two processes entered the product develop- 
ment phase, in which the problems to be solved were specified to a higher degree, both companies chose to operate in a modular way - Probi in collaboration with Skånemejerier, and Valio by utilizing its traditional, departmental structure. It should be noted, however, that we are unable to find a simple relation between problem structure and the appropriate mode of knowledge networking, because both problem structure and knowledge networking are complex entities. As argued before, we need to see problem structures as a continuum, from indefinite to very well defined. We may also need to distinguish between different dimensions of a problem definition, specificity perhaps being just one of them. Similarly, the categories of knowledge networking - pioneer and modular - that have dominated this analysis are very broad, and need to be further decomposed into sub-categories, if a more detailed discussion about the management of learning and knowledge production is to be made possible.

\section{Knowledge Networking Analysis as a Perspective on Studying Innovation}

What does our conceptual framework do for understanding the process of knowledge networking as part of the research and innovation activities of the two companies, with respect to the LGG and Lp299v development processes? We can, at the moment, discern two main answers to this question. First, as we saw in the foregoing discussion, the challenges that different kinds of companies are presented with in embarking on the road to innovation open up in an illuminating way. Why is it so hard for large, traditional companies-admittedly with an honourable history of valuing research and development - to bring forth radical innovations? It is likely because their predominantly modular way of organizing knowledge networking can easily hinder the kind of communication necessary for giving birth to such innovations. Why is it that small science companies experience difficulties in the commercialization phase? It is probably because their predominantly pioneer way of functioning needs to be combined with that of modularity. Needless to say, our perspective is still at a developing stage, but it does sem to be on its way to enabling more explanatory power.

Second, our conceptual platform sheds some analytical light on the nature of the challenges that these two different kinds of companies face at various stages in the innovation process, and the kind of knowledge networking strategy that would be appropriate for solving them. Does that understanding of differences help us, in a more general way, to distinguish with greater precision the types of organizations that are active in the commercialization of science? This helps us with our efforts to distinguish between the common (and often casually-used) notion of 'science-based companies', and our empirical observation of what we call 'science companies'. Does the transepistemic challenge have clear-cut contours, or does it rather present itself as an amoeba-like, fluctuating phenomenon? Perhaps it is something in between? When is it more appropriate to respond to challenges by applying the principles of modularity, rather than pioneering knowledge networking, or, for that matter, translational knowledge networking? As mentioned above, the continuing exploration of the 
notion of transepistemic challenge, itself a conceptual novelty first presented and formulated in this paper, is an obvious and central part of our research agenda.

By using this conceptual framework, we have learned that the processes of knowledge integration are more diverse, contingent and influential than previously described. From the organizational and innovation perspectives, the process of the actual work of researchers in integrating knowledge, both among themselves as representatives of various traditions, disciplines and fields, and between researchers and other organizational members, such as salespeople, managers and marketers, is often left undescribed, unanalyzed and taken-for-granted, in effect seen as a black box. Our work using the concepts above shows how the different structures and processes of carrying out the integration of knowledge have importance for assessing the risks and appropriateness of different organizational strategies for innovation. For example, by looking at what happens within the processes of knowledge integration, we have learned that one form of knowledge networking, even if ultimately successful, may at some point in its process lead the organization - and its hopes of achieving a fruitful innovation - dangerously close to failure. The same form of knowledge networking, in another time and another form of organization, may prove vital for saving an innovation from abandonment. Knowing more about what happens to the communication, integration and generation of knowledge during an innovation process is valuable for ensuring its success. The conceptual framework we have developed, and will continue to refine, is a useful tool for achieving greater detail, accuracy and understanding of such knowledge integration processes.

\section{Acknowledgements}

This research was funded by Academy of Finland (SCulBio 2000, project number 49974) and TEKES, the Finnish National Technology Agency (ManTra, project number 2726/3101). Additionally, we thank all of our respondents for their active and generous participation in this research.

\section{References}

Abbott, A.

1988 The System of Professions: An Essay on the Division of Expert Labor. Chicago: University of Chicago Press.

Antonsson, M., Ardö, Y., Nilsson, B.F. \& Molin, G.

2001 'Screening of Lactobacillus Strains in a Cheese Model System Designed for Selection of Adjunct Cultures.' Ch. 3 in Antonsson, Lactobacillus in Semi-Hard Cheese and Their Use as Adjunct Cultures. Ph.D. dissertation. Lund University, Sweden.

Apostel, L., Berger, G., Briggs, A. \&

Michaud, G. (eds.)

1972 Interdisciplinarity: Problems of Teaching and Research in Universities. Paris: OECD.

Becher, T. \& Trowler, P.R.

2001 Academic Tribes and Territories: Intellectual Enquiry and the Culture of Disciplines. Second ed.. Buckingham, UK: Open University Press. 
Berggren, A., Nyman, M., Björk, I., Johansson, M.-L. \& Molin, G.

1996 Short-Chain Fatty Acid Content in the Hind-Gut of Rats: Impact of Dietary Supplementation With Lactobacilli.' Ch. 4 in Berggren, Formation, Pattern and Physiological Effects of ShortChain Fatty Acids: Impact of Various Indigestible Carbohydrates and Probiotics on Hind-Gut Fermentation Using Rat Experimental Models. Ph.D. dissertation. Lund University, Sweden.

Carlile, P.R.

2002 'A Pragmatic View of Knowledge and Boundaries: Boundary Objects in New Product Development.' Organization Science 13, 4: 442-55.

D'Adderio, L.

2001 'Crafting the Virtual Prototype: How Firms Integrate Knowledge and Capabilities Across Organisational Boundaries.' Research Policy 30: 1409-24.

Dougherty, D.

1992 'Interpretive Barriers to Successful Product Innovation in Large Firms.' Organization Science 3, 2: 179-202.

Espelund, G.

1996 'Identifying the Miniscule.' Probi International Update for Probiotics and Functional Foods 2: 6-8.

1997 'Oats in the Limelight.' Probi International Update for Probiotics and Functional Foods 1: 6-8.

Fujimura, J.

1996 Crafting Science: A Sociohistory of the Quest for the Genetics of Cancer. Cambridge, MA: Harvard University Press.

Gorbach, S. M.

1996 'The Discovery of Lactobacillus GG.' Nutrition Today 31, 6 (Supplement, Nov-Dec).

Goldin, B.R., Gorbach, S.L., Saxelin, M., Barakat, S., Gualtieri, L. \& Salminen, S. 1992 'Survival of Lactobacillus Species (Strain GG) in Human Gastrointestinal Tract.' Dig. Dis. Sci. 37: 121-28.

Isolauri, E., Juntunen, M., Rautanen, T., Sillanaukee, P. \& Koivula, T.

1991 'A Human Lactobacillus Strain (Lactobacillus Casei Sp. Strain GG) Promotes Recovery From Acute Diarrhoea in Children.' Pediatrics 88: 90-97.
Johansson, M.-L., Sanni, A., Lönner, C. \& Molin, G.

1995 'Phenotypically Based Taxonomy Using API 50CH of Lactobacilli From Nigerian Ogi, and the Occurrence of Starch Fermenting Strains.' Ch. 3 in Johansson, Systematics and Starter Culture Selection of Lactobacillus for Human Intestine and Nigerian ogi, with special reference to Lactobacillus plantarum. Ph.D. dissertation. Lund University, Sweden.

Jönsson, M.

1996 'A Professor Tackles Probiotics.' Probi International Update for Probiotics and Functional Foods 1: 6-8.

Keating, P. \& Cambrosio, A.

2003 Biomedical Platforms: Realigning the Normal and the Pathological in LateTwentieth-Century Medicine. Cambridge, MA: MIT Press.

Klein, J.T.

1996 Crossing Boundaries: Knowledge, Disciplinarities, and Interdisciplinarities. Knowledge: Disciplinarity and Beyond Series. Charlottesville, VA: University Press of Virginia.

Lagnevik, M., Sjöholm, I., Lareke, A. \& Östberg, J.

2003 The Dynamics of Innovation Clusters: A Study of the Food Industry. New Horizons in the Economics of Innovation Series. Cheltenham, UK: Edward Elgar.

Langlais, R. \& Bruun, H.

1998 'The Human Dimensions of Interdisciplinarity - An Overview of the SCANTRAN Experience.' Pp. 227-35 in Hukkinen, Turunen, Heal \& Holten (ed.), A Terrestrial Transect for Scandinavia/Northern Europe: Proceedings of the International SCANTRAN Conference. Ecosystems Research Report 31. Brussels: DGXII, European Commission.

Murray, F.

2002 'Innovation as Co-Evolution of Scientific and Technological Networks: Exploring Tissue Engineering.' Research Policy 31, 8-9: 1389-1403.

Mäyrä-Mäkinen, A.

2000 ' 10 Years of Gefilus Products - What Have We Learned?' LGG Action Newsletter 1: 2 . 
Snow, C.P.

1959/ 1998 ‘The Rede Lecture, 1959.' Pp. 1-51 in The Two Cultures: A Second Look. Cambridge, UK: Cambridge University Press.

Star, S. L. \& Griesemer, J. R.

1989 'Institutional Ecology, 'Translations' and Boundary Objects - Amateurs and Professionals in Berkeleys Museum of Vertebrate Zoology, 1907-39.' Social Studies of Science 19: 387-420.

Tress, B., Tress, G., van der Valk, A. \& Fry, G. (eds.)

2003 Interdisciplinary and Transdisciplinary Landscape Studies: Potential and Limitations. Wageningen, The Netherlands: Delta Series 2.

Vareman, K.

1999 'New Thinking Backed Up by Science.' Probi International Update for Probiotics and Functional Foods 1: 2.

Wallter, M.

2002 'Message From the CEO'. Pp. 4-5 in Probi AB: A Biotechnology Company in Probiotics. Annual report for 2001. Lund, Sweden: Probi.

Weingart, $\mathrm{P}$.

2000 'Interdisciplinarity: The Paradoxical Discourse.' Pp. 25-41 in Weingart \& Stehr (ed.), Practicing Interdisciplinarity. Toronto: University of Toronto Press.

Wenger, E.

1998 Communities of Practice: Learning, Meaning, and Identity. Cambridge, UK: Cambridge University Press.

Richard Langlais, Nina Janasik \& Henrik Bruun

Laboratory of Environmental Protection Helsinki University of Technology

Helsinki, Finland

Corresponding author:

richard.langlais@hut.fi 